\title{
Problemorientering set fra tre uddannelsers perspektiv
}

Tina Bering Keiding, lektor, ph.d. Danmarks Padagogiske Universitetsskole, Aarhus Universitet

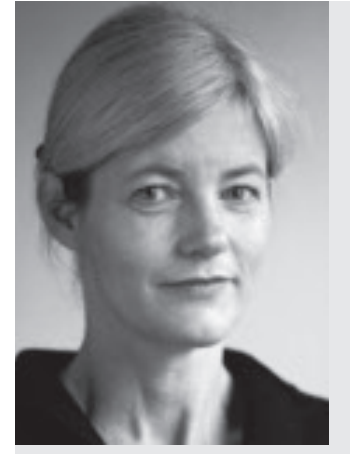

Tina Bering Keiding er ansat ved Forskningsprogrammet for de videregående uddannelsers pædagogik, Institut for Didaktik, DPU. Aktuelt koncentrerer hendes aktiviteter sig om tre temaer Rummet som kontekst for læring, som undersøger Arkitektur \& Design studerendes oplevelse af fordele og ulemper ved henholdsvis individuelle projektgrupperum og tegnesal som ramme for projektarbejde, herunder en analyse af fænomenet 'adgang til inspiration'. Indholdsudvælgelse i videregående uddannelse, som har til hensigt at undersøge kriterierne for, at et givet tema henholdsvis indlemmes i eller udgår af et curriculum, herunder spørgsmålet om tematrængsel. Klasserumsobservation, som sigter på at udvikle en systemteoretisk genbeskrivelse af deltagende observation som teknik til frembringelse af empirisk information.

\section{Reviewet artikel}

Artiklen rejser sporgsmålet om og $i$ givet fald hvorledes problembegrebet fremstår som et relevant begreb for beskrivelse og refleksion af projektorganiseret undervisning, sådan som den aktuelt udfolder sig på tre uddannelser på Aalborg Universitet. Den konkluderer, at problemorientering $i$ klassisk forstand ikke har nogen betydning på de tre uddannelser. To af uddannelserne finder problembegrebet problematisk i forhold til uddannelsens faglighed. På alle uddannelser er der tale om eksemplariske og didaktisk tilrettelagte problemer, som refererer til uddannelsens hensigt og indhold, frem for til noget uden for denne. Derimod tildeles projektbegrebet og projektet som organiserende princip en central plads $i$ beskrivelsen af metoden.

\section{Program}

Artiklen beskriver, hvorledes den undervisningsform, der $\mathrm{i}$ daglig tale kaldes problemorienteret projektarbejde, iagttages på tre uddannelser på De Ingeniør, $\mathrm{Na}$ tur- og Sundhedsvidenskabelige Fakulteter på Aalborg
Universitet (AAU). Hensigten er dels at beskrive, hvad forskellige iagttagere tematiserer, når de bliver bedt om at forholde sig til begrebet problemorientering og dets betydning i uddannelsen, dels at sammenligne disse beskrivelser med henblik på at undersøge, hvorvidt der kan iagttages forskelle og ligheder mellem de tre uddannelser. Hvordan forholder uddannelsens deltagere sig til begrebet problemorientering? Tager metoden form af det specifikke genstandsfelt? Og i givet fald, hvordan? Hvad er ens og hvad er forskelligt?

Artiklen bygger på et forskningsprojekt gennemført i samarbejde med De Ingeniør, Natur- og Sundhedsvidenskabelige Fakulteter og Pædagogisk Udviklingscenter på Aalborg Universitet. Forskningsprojektet er i sin helhed afrapporteret i Keiding \& Laursen (2008). I rapporten berøres en række temaer ud over problemorientering, blandt andet projektets hensigt, eksemplaritet, deltagerstyring.

\section{Baggrund og universitetsdidaktisk relevans}

Projektorganiseret undervisning er ikke et nyt fænomen, hverken i uddannelsessystemet eller i den teoretiske didaktik. I dansk universitetsdidaktik kommer projektorganiseret undervisning for alvor på banen ved oprettelse af Aalborg Universitet og Roskilde Universitets Center, hvor den skulle bidrage til at give disse 'nye' universiteter en egen pædagogisk profil (Keiding \& Laursen, 2008). Siden har projektarbejdet, som det ofte kaldes i daglig tale, været genstand for en lang række diskussioner, evalueringer og nyudviklinger på disse institutioner. Efter årtusindskiftet vinder en ny betegnelse udbredelse på Aalborg Universitet. I tråd med 1990'ernes "fra undervisning til læring« regime, og fremkomsten af det angelsaksisk-inspirerede ${ }^{1}$ koncept Problem Based Learning (PBL), udskiftes betegnelsen problembaseret projektorganiseret undervisning med PBL, og metoden betegnes herefter som The Aalborg PBL-model (fx Kolmos m.fl., 2004). Det er under denne betegnelse, modellen nu søges akkrediteret. 
I de teoretiske beskrivelser og af den uddannelsesmæssige praksis spiller begrebet problemorientering en central rolle (Berthelsen m.fl., 1977; Illeris, 1976; 1985; Mathiesen, 1999; Ulriksen, 1997). Kolmos \& Krogh (2002), Kolmos m. fl. (2004).

Dette rejser spørgsmålet om, hvorledes disse beskrivelser forholder sig til metodens aktuelle konkrete anvendelse i uddannelsernes undervisningsmæssige praksis, og dermed om og på hvilke måder de teoretiske beskrivelsers begreber er hensigtsmæssige i forhold til at beskrive og italesætte uddannelsesmæssig praksis. Artiklen bygger ikke på nogen præmis om, at teori skal ligne i betydningen være lig med praksis eller omvendt, men samtidig synes det oplagt, at en didaktisk teori skal kunne tematisere centrale undervisningsmæssige perspektiver, hvis den skal fungere som refleksionsteori for en given undervisningsform.

\section{Analysestrategi}

Teoretisk og metodisk baserer de empiriske iagttagelser sig på systemteoretisk teori og metode. Heri står begreber som iagttagelsespunkt (hvorfra iagttages) og ledeforskelle (hvad iagttages) centralt (fx Keiding, 2005; Keiding \& Laursen, 2008). Iagttagelserne knytter sig til 3 uddannelser på De Ingeniør, Natur- og Sundhedsvidenskabelige Fakulteter ved Aalborg Universitet:Arkitekturlinjen på Arkitektur \& Design (A\&D), Industri/ energiteknik $^{2}$ og Matematik. De tre uddannelser er valgt ud fra et kriterium om forskellighed og repræsenterer henholdsvis kombinationen ingeniørvidenskab/æstetisk videnskab, ingeniørvidenskab i klassisk forstand og naturvidenskab. Antagelsen bag dette valg er, at hvis projektmetoden og, med særlig relevans for denne artikel, betydningen af problemorientering tager form af den aktuelle uddannelses kundskabsprofil, vil disse uddannelser qua den fagspecifikke forskellighed gøre det muligt at indfange dette.

På hver uddannelse beskrives projektmetoden fra to iagttagelsespunkter, henholdsvis undervisere og studerende. Baggrunden er et ønske om at kunne identificere, hvorledes deltagere med forskellige roller i forhold til undervisningen iagttager denne. Der er gennemfort et interview med en eller to undervisere fra hvert uddannelsesområde. Fælles for disse er, at de har haft en fremtrædende rolle i formuleringen af de respektive uddannelser, hvad angår ide, form og indhold. Deraf betegnelsen nøglepersoner. Endvidere er der gennemført 12 gruppeinterviews med studerende, fordelt med to grupper på bachelorniveau og to på kandidatniveau. Interviewene er gennemført ud fra en række ledeforskelle, som svarer til centrale temaer i projektmetoden.

I relation til denne artikel er de empiriske data analyseret gennem iagttagelse af kommunikationens sagsdimension, dvs. iagttagelse af hvad der betegnes, inden for ledeforskellen problemorientering.
For yderligere beskrivelse af empirisk metode henvises til Keiding \& Laursen (2008).

\section{Iagttagelse af problembegrebet: Interviews med nøglepersoner}

Nøglepersonen på A\&D udtrykker gennem interviewet tvivl om, hvorvidt problembegrebet ud fra et uddannelsesfagligt blik meningsfuldt kan tildeles en så central placering i projektmetoden på $\mathrm{A} \& \mathrm{D}$, som det har i Aalborg-modellen. Indledningsvist gennem tematisering af, at formgivning rummer en intuitiv, legende dimension (NP-A\&D:5, evt. også Kiib, 2004, hvori begrebet 'play' introduceres i relation til metoden) og lidt senere med formuleringer som: »Det er jo ikke altid at design handler om at løse et problem«. Fokus i projekter kan lige så vel være, at design »skal opfylde nogle behov som jeg [som bruger, tbk] ikke selv rigtig er klar over" (NP-A\&D:9).

Problemorientering står således ikke centralt i projektmetoden på A\&D. Derimod fremhæver nøglepersonen eksplicit projektbegrebet som afgørende for uddannelsens faglighed: "Det var jo, altså projekter har vi jo aldrig haft problemer med, det har ligget i vores faglighed altid. [...]. Man kan sige, at den [den klassiske problemorientering, tbk] giver en bestemt optik på et mere universelt læringskrav, altså et læringssystem. Jeg tror da man skal være trofast overfor Aalborg modellen, fordi den har vist sin berettigelse og succes langt hen ad vejen, men derfor tror jeg godt den kan suppleres med nogle andre ting i kortere eller længere sekvenser" (citat NP-A\&D:26, men også NP-A\&D:12). I stedet for begrebet problem benytter nøglepersonen begreberne koncept og program til karakterisering af projekterne. Konceptet henviser til den forestillingsramme, som indrammer projektet, mens programmet kan ses som konkretisering af konceptet (Keiding \& Laursen, 2008).

Også på Matematik udtrykkes forbehold over for problembegrebet. Især den form, problemorienteringen havde i universitetets første år, og som var stærkt inspireret af 1970'ernes tolkning af problembegrebet, synes at have været vanskeligt forenelig med uddannelsens hensigt og interesse: „Nu skulle man til at argumentere op og ned ad vægge og stolper for at der var et problem. Der var ikke noget problem. Jeg havde bare lyst til at lave noget matematik og det var der også nogle af de studerende der havde og så skulle man til, »hvordan får vi det nu formuleret, så vi redder menneskeligheden, fordi.. [anden informant indskyder]: Det skal være synd for nogen [første informant forsætter] Jo det skal være synd for nogen og det var altså noget af en udfordring « (NP-Mat:11).

Gennem årene har forståelsen af problemorientering ændret sig, således at det er blevet legalt at beskæftige sig med faginterne problemer (NP-Mat:11). Ikke desto mindre udtrykkes stadig et forbehold over for begre- 
bet: „Vi vil hellere sige at det er projektbaseret læring [...] Ja og procesbaseret.Vi gør hvad vi kan for at styre udenom det ord der [problemorientering, tbk] (NPMat:21).

Nøglepersonen fra Industri/energiteknik synes ikke at se nogen problemer i ideen om problemorientering. Projekterne udspringer i vid udstrækning af praktiske og/eller vidensmæssige problemer fra produktionsvirksomheder. Samtidig transformerer uddannelsen gennem stram styring disse praktiske problemer til uddannelsesprojekter, og det er tydeligt, at det er uddannelsens mål og indhold og ikke virksomhedernes interesse, der er afgørende for den konkrete problemstilling: "Altså vi siger: her er der noget at komme efter, det er en relevant problemstilling i forhold til temaet, vi forventer at kunne arbejde med et rimeligt niveau [...] Og så tager vi en snak med virksomheden inden og fortæller lidt om, hvordan vi forventer at tingene kører. Altså kan man løse det med en dialog er det jo selvfølgelig det bedste, men ellers er det de studerende der bestemmer, altså i samråd med os « (NP-Industri/ energi:13).

Her har problemorienteringen en lighed med 1970 'ernes problembegreb ved at problemet refererer til noget uden for uddannelsessystemet - et såkaldt 'virkeligt' problem. Samtidig er der to afgørende forskelle. Dels $i$ at det konkrete problem ikke søges indplaceret i en samfundsmæssig/politisk kontekst. Dels i at det ikke er løsningen af det konkrete problem, men uddannelsens mål, der definerer projektet og dets specifikke indhold.

\section{Iagttagelse af problembegrebet: Studenterinterviews}

De studerende fra Energiteknik/industri formulerer sig omkring problemorientering på en måde som viser, at anvendelse af begrebet problem og beskrivelse af projekter som problemorienterede opleves at fungere hensigtsmæssigt $\mathrm{i}$ forhold til de konkrete projekter. Eksempelvis fra et af bachelorprojekterne: »Altså til vores projekt $i$ hvert fald fik vi sådan nogle hints til det, at der var nogle problemer med spændet, der var nogle steder det bryder, [...] og så var vi ude at snakke med en major fra jægerkorpset, som så havde interviewet nogle af jægersoldaterne som så kunne sige, at det lige præcist var der det gik i stykker og i de og de situationer [...]. Og så ud fra hvad han har sagt formulerer vi nogle problemer og så går vi ind og ser på dem« (E4-0009).

Studenterne fra Matematik udtrykker derimod forbehold over for problembegrebet, når der spørges til, hvordan de kommer frem til projektets problemformulering: "Det gør vi ikke, vi har ingen problemformulering «[...] Vi har ikke noget som sådan vi arbejder hen imod, vi tager relevante ting, som er interessante og sætter os ned og forstår dem« (MAT6-0019).
Tilsvarende forbehold over for selve begrebet udtrykkes af studenterne på A\&D: »Altså noget er givet på forhånd, men vi har det ikke så godt med det der problem der, for det er et krav vi helst ikke [...] Altså den overordnede problemstilling bliver jo givet fra forelæserne eller semesterkoordinatorerne. Altså, problemformuleringen er sådan lidt formuleret $\mathrm{i}$ ganske få sætninger, men derudover har vi 4 sider med designkriterier, altså det er lidt på den måde vi arbejder, hvor vi har en masse kriterier for, hvad det er for et design vi gerne vil komme frem til«(A\&D8-0013).

\section{Diskussion: Fra problemorientering til projektorganisering}

Fælles for interviewene med nøglepersoner og studerende er, at deres problembegreb adskiller sig afgørende fra den forståelse, der beskrives i projektmetodens teoretiske grundlag fra 1970'erne og som er fremherskende i de beskrivelser af modellen, som tidligere har været foretaget i relation til AAU (fx Adolphsen \& Qvist, 1999; Kjærsdam, 1994; Kolmos \& Krogh, 2002).

Projekternes problemer tager for det første ikke afsæt i deltagernes erfaringer og noget, som de personligt oplever som problematisk. For det andet er der ikke nødvendigvis tale om problemer af bred samfundsmæssig betydning. Endelig fastlægges udfaldsrummet for løsning af problemet med uddannelsen og dennes målsætninger som referencepunkt. Problemet og projektets indhold tilpasses til uddannelsen, mens det i den oprindelige projektmetode var problemet, der definerede hvilke uddannelseselementer, der var aktuelle. Der er med andre ord tydeligt tale om didaktisk tilrettelagte problemer og projekter, som refererer til den specifikke uddannelse, ikke til noget uden for uddannelsen.

Både på A\&D og på Matematik synes problembegrebet uegnet til en generel karakteristik af projekterne, mens det på Industri/energiteknik synes at tilbyde en hensigtsmæssig begrebsramme. På A\&D anfører nøglepersonen, at problemorienteringen tilbyder et alt for snævert blik på feltet. Design handler ikke nødvendigvis om at løse problemer. Også de studerende er forbeholdne over for problembegrebet, dog uden at specificere dette forbehold nærmere. Det samme gælder matematik, hvor projekternes specifikke hensigt heller ikke er at løse konkrete problemer inden for det specifikke emne, men at beskrive og forstå matematiske tematikker/problemstillinger, der optræder i relation til emnet.

Derimod fremhæver både A\&D og Matematik selve projektbegrebet og den processuelle dimension som noget centralt. Også nøglepersonen fra Industri tematiserer projektorganiseringen og det åbne udfaldsrum, og de studerendes tagen ejerskab til projektet som centrale kvaliteter ved metoden (Keiding \& Laursen, 2008).

I dette perspektiv, samt i lyset af, at det netop er projektorganiseringen og ikke problemorienteringen, 
der beskrives som det didaktiske princip, som skal indfri uddannelsernes almene kompetencer (RSO-2007), synes det ganske tankevækkende, at projektbegrebet er forsvundet fra metodens nuværende officielle betegnelse (The Aalborg PBL-Model) til fordel for problembegrebet.

Den teoretiske genbeskrivelse i Keiding (2008) foreslår, at begreberne problemorientering og problemformulering udskiftes med de mere almene betegnelser hensigt og program. Herved bliver projektmetodens nøglebegreb netop projektet og den type af målrettede og forlods ubestemte forehavender/hensigter, som dette begreb beskriver. Programmets funktion er at operationalisere projektets hensigt på en måde, som tjener til projektets løbende bestemmelse af og refleksion over sig selv. I forhold til de her beskrevne projekter synes en sådan beskrivelse at kunne indfange projektmetodens variationsformer, sådan som de optræder i denne sammenhæng, og dermed som en almen projektdidaktisk kategori. Hensigten vil angive projektets overordnede retning. Et program vil bidrage til at fastlægge kriterier for de processer, der skal indfri hensigten, uanset om den er problemløsende, forståelsesorienteret, nyskabende. Det synes således relevant dels at overveje, om projektbegrebet skal genintroduceres som et konstituerende begreb for metoden, samt at genoverveje det hensigtsmæssige $\mathrm{i}$ at opretholde problemorientering som et kardinalpunkt.

Gennem iagttagelserne af problembegrebet bliver det som nævnt tydeligt, at det er den specifikke uddannelse, og ikke problemstillinger uden for denne, der former projekternes hensigt, indhold og form. Der er med andre ord tale om, hvad man kan kalde didaktisk tilrettelagte projekter. Dette formuleres meget eksplicit af nøglepersonen fra Energiteknik, når vedkommende siger at virksomhedernes forslag skal gennem uddannelsens filter (NP-Industri/energi:13).

Samtidig handler projekterne om noget konkret. Projekterne kommer dermed til at operere med en dobbelt hensigt - en undervisningsmæssig og en projektspecifik - hvor indfrielse af den konkrete, projektspecifikke hensigt dels bliver et mål i sig selv, dels et medium for læring. Studerende fra matematik siger således, at projektet indrammes af en konkret problemstilling, men samtidig er det tydeligt, at det ikke er løsningen af den specifikke problemstilling, der driver projektet: "Jeg tror det mest vigtige ved det, det er de værktøjer man lærer til at angribe problemstillingen, det er ikke sådan så meget selve problemet. Det er tankegangen og tilgangen, altså det er teknikker og værktøjer meget mere end det er det konkrete, det kan man reelt set ikke bruge til noget« (MAT6-0020).

På A\&D og Energiteknik tildeles det konkrete projekt større opmærksomhed. Samtidig er det klart, at selv når projektets konkrete hensigt og indhold omtales, sker det med reference til uddannelsen og det aktuelle semesters mål: „Forstået på den måde, at det ikke er vigtigt, at det lige er et spænde selvfølgelig, det er mere det vi gør ved det. Der et det jo igen det der, at man opfylder sin studieordning, så man rent faktisk lærer noget man kan bruge fremover" (E4-0016). Og fra A\&D: »Det er også derfor vi opstiller de der læringsmål, altså en stor del af det, det er jo selve processen og produktet er jo så bare noget der følger med, så længe vi er under uddannelsen i hvert fald" (A\&D4-0021). Det blik for den dobbelte hensigt, som tematiseres i alle studenterinterviews (Keiding \& Laursen 2008) antyder, at de studerende kan identificere de generelle og dermed uddannelsesrelevante kundskaber, der tilegnes gennem det konkrete projekt. Projekterne genkendes med andre ord som eksemplariske i forhold til uddannelsernes indhold. Dette blik for det eksemplariske er ganske overraskende set i relation til de bekymringer, der gennem årene har været om, hvorvidt de studerende kan generalisere og dermed identificere det almene i konkrete projekter. Desværre tillader det aktuelle materiale ikke at forfølge temaet yderligere.

\section{Konvergente og eksplorative projekter}

Beskrivelserne synes at antyde en forskel i de mål, der skal indfris gennem projekterne, og dermed muligvis også forskelle i projekttyper.

På både A\&D og Industri/energiteknik synes projekterne at orientere sig mod formulering af konkrete svar/løsningsforslag i forhold til et konkret design, eller et konkret element $\mathrm{i} /$ aspekt af en produktionsproces. Projekterne synes med andre ord at konvergere mod ét blandt flere mulige svar. Noget skal beskrives, forstås og formgives; et spænde, en proceslinje, en bygning, en model. Men der er ikke nødvendigvis tale om, hvad Laursen (1994) betegner som problemløsende projekter. Der kan også være tale om at formulere nye muligheder, nye forslag uden at dette tager udgangspunkt $\mathrm{i}$ problemer med det nuværende. Både den konvergente karakter og en tydelig faseopdeling af projekterne ses i interviews og rapporter fra disse uddannelser (Keiding \& Laursen, 2008). Projektstrukturen minder dermed om den, der med fisken som metafor er beskrevet i Fisker \& Keiding (2002).

På Matematik antyder interviewene, at der er tale om projekter, som udfolder en tematik, som nok er aktuel uden for matematikken, eksempelvis kommunikation over støjfyldte kanaler, men hvor det tydeligvis ikke handler om at komme frem til svar på et konkret spørgsmål eller løse et konkret problem, men om at beskrive og analysere dette tema matematisk både i bredden og i dybden. Billedligt synes projekterne snarere at kunne beskrives gennem en træ- eller fraktal-metafor, hvor hvert tema kan forgrene sig i undertemaer eller afsluttes og en ny gren afsøges. Man kan således betegne disse projekter som eksplorative. Hvorvidt dette er en forskel, som udelukkende knytter sig til de aktuelle fagområder, eller der er tale om generel forskel mellem 
ingeniørvidenskabelige og naturvidenskabelige uddannelser, kan det aktuelle materiale ikke sige noget om.

\section{Konklusion}

Beder man nøglepersoner og studerende fra tre forskellige uddannelser under De Ingeniør-, Natur- og Sundhedsvidenskabelige Fakulteter ved AAU om at forholde sig til begrebet problemorienteret projektarbejde og dets betydning i uddannelsen, er der flere ting, der falder i øjnene.

For det første, at især Arkitektur \& Design samt Matematik er forbeholdne over for problembegrebet og ideen om problemorientering. På disse uddannelser handler projekterne ikke nødvendigvis om at løse problemer. Uddannelserne foretrækker således at lægge vægt på projektbegrebet. Et begreb som også fremhæves af Industri/energiteknik, uagtet at problemorientering, så længe der er tale om didaktisk tilrettelagte problemer, synes at fungere hensigtsmæssigt i denne uddannelse. Det må derfor overvejes om den almendidaktiske tilgang, der tilbydes via den teoretiske genbeskrivelse, i højere grad end de nuværende begreber om problemorientering og PBL tilbyder uddannelserne hensigtsmæssige begreber til at beskrive sig selv.

For det andet at projekterne opererer med en dobbelt hensigt, dels en projektspecifik, dels en uddannelsesmæssig. Det er uddannelsen og dennes målsætninger og indholdskrav, som udgør de afgørende kriterier for valg af indhold, og ikke den specifikke problemstilling. De studerende synes dermed at have blik for, at projekterne ikke handler om 'en virkelighed' uden for uddannelsen, men er medier til læring af uddannelsesmæssige relevante kundskaber. Hvorledes dette blik for projekternes eksemplariske værdi tilvejebringes $\mathrm{i}$ uddannelsen, kan desværre ikke belyses via materialet.

For det tredje synes der at kunne identificeres to forskellige typer af projekter. På A\&D og Industri/ energiteknik synes der at være tale om konvergente projekter, som orienterer sig mod ét blandt flere mulige svar/løsninger, mens projekterne på matematik synes at have en mere eksplorativ karakter, hvor projektet snarere udfolder og udforsker et felt end frembringer konkrete svar på et konkret spørgsmål.

\section{Referencer}

Adolphsen, J. \& Qvist, P. (1999, 2. udgave). ABC i problemformulering, problemløsning og projektskrivning. København: Gyldendal Undervisning.

Berthelsen, J.; Illeris, K., \& Poulsen, S. C. (1977). Projektarbejde erfaringer og praktisk vejledning. København: Borgen

Fisker, A. M. \& Keiding, T. B. (2005). Det arkitektoniske hovedgreb. I: L. Botin \& O. Pih (red.) Pandoras boks: metodeantologi (s. 31-58). Aalborg: Aalborg Universitetsforlag/Arkitektur \& Design, Aalborg Universitet, 2005.

Hopmann, S. (2007). Restrained Teaching: the common core of Didaktik. European Educational Research Journal, 6(2), 109-124.

Illeris, K. (1976) [opr. 1974]. Problemorientering og deltagerstyring. Oplag til en alternativ didaktik. København: Munksgaard

Illeris, K. (1985) [opr. 1981]. Modkvalificeringens padagogik. København: Unge Pædagoger.

Keiding, T.B. (2005). Hvorfra min verden går. Et Luhmann-inspireret bidrag til didaktikken. Ph.d.-afhandling. Aalborg: Aalborg Universitet, Institut for Uddannelse, Læring og Filosofi

Keiding,T. B. (2008). Projektmetoden - en systemteoretisk genbeskrivelse. Dansk Universitetspaedagogisk Tidsskrift, 5, 22-29

Keiding,T. B., \& Laursen, E. (2008). Projektmetoden iagttaget. Metodens didaktik og anvendelse $i$ universitetsuddannelse. Forskningsrapport. Aalborg: Aalborg Universitet, Institut for Uddannelse, Læring og Filosofi. http://www.learning.aau.dk/index.php?id=29 (tilgået 04.01.2008)

Kiib, H. (2004). PBL in Architecture and Design. I: A. Kolmos m. fl. (red.). The Aalborg PBL-model. Progress, diversity and challenges. Aalborg: Aalborg University Press

Kolmos, A. \& Krogh L. (2002) (red.) Projektpadagogik i udvikling. Aalborg: Aalborg Universitetsforlag

Kolmos, A., Fink, F., \& Krogh, L. (2004) (red.). The Aalborg PBLmodel. Progress, diversity and challenges. Aalborg: Aalborg University Press

Kjærsdam, F. (1994) The Aalborg Experiment -Tomorrow's Engineering Education. European Journal of Engineering Education, 19(3).

Laursen, E. (1994). Evaluering af den samfundsvidenskabelige basisuddannelse på Aalborg Universitet: 3. rapport. Problembaseret Projektarbejde. Aalborg: Aalborg Universitet

Mathiesen, A. (1999) (red.). Projektarbejde i praksis - om uddannelsesproblemer i 90'ernes Danmark. København: Unge Pædagoger

RSO (2007). Rammestudieordning. Teknisk videnskab, Naturvidenskab, Sundhedsvidenskab. De Ingeniør-, Natur-, og Sundhedsvidenskabelige Fakulteter. Aalborg Universitet. http:// adm.aau.dk/fak-tekn/regler/rso.pdf

Ulriksen, L. (1997). Projektpadagogik - hvorfor det? Roskilde: Erhvervs- og uddannelsesgruppen, Roskilde Universitetscenter

\section{Noter}

1 Hopmann (2007) tilbyder en meget udmærket beskrivelse af nogle af kardinalforskellene mellem hhv. den tyske didaktiktradition og den angel-saxiske curriculumtradition

2 På undersøgelsestidspunktet fandtes Energiteknik udelukkende som kandidatuddannelse. På bachelordelen fulgte de studerende fælles forløbet for Industri og Global Forretningsudvikling. På kandidatdelen følges specialiseringen Strømnings- og Forbrændingsteknik (FACE). 